\title{
Antecedents of perceived entrepreneurial ability in Catalonia: the individual and the entrepreneurial context
}

\author{
Manoj Chandra Bayon ${ }^{1 *}$, Yancy Vaillant ${ }^{2}$ and Esteban Lafuente ${ }^{3}$
}

\author{
* Correspondence: \\ bayonmc@gmail.com \\ ${ }^{1}$ School of Business, Universidad Del \\ Norte, Km 5 via Puerto Colombia, \\ Barranquilla, Colombia \\ Full list of author information is \\ available at the end of the article
}

\begin{abstract}
Purpose: The main purpose of this study is to examine the antecedents of perceived entrepreneurial ability within a given context.

Design/methodology/approach: Taking the cognitive approach we examine the role of several individual-level factors and the entrepreneurial context in the form of personal knowledge of other entrepreneurs and territorial location in influencing positive perceptions of entrepreneurial ability. The proposed hypotheses are tested on a dataset of 1961 respondents randomly selected from the adult population in Catalonia region in Spain.
\end{abstract}

Findings: Our results reveal that among the individual level factors, a median level of education, experience (both prior entrepreneurial experience and job), task specific knowledge and age have a significantly positive influence on perceived entrepreneurial ability in Catalonia. However, among the entrepreneurial context it is the knowledge of other entrepreneurs rather than territorial location that have a significantly positive influence on perceived entrepreneurial ability.

Originality/value: Previous studies have reported that nascent entrepreneurs tend to have significantly favourable perceptions of their entrepreneurial ability. In this study using the cognitive learning framework we examined the antecedents of such perceived entrepreneurial ability thereby extending the stream of studies that look at pre-entry factors that influences entrepreneurial cognitions. The value of our research is in identifying and explaining the combined role of individual-level resources and the contextual environment in influencing one of the most important drivers of nascent entrepreneurship in an economy.

Implications: The main implication of our study is that favourable perceptions of entrepreneurial ability can be influenced through participatory learning as well as behavioural modelling. Our study points to several ways through which favourable perception of entrepreneurial ability can be influenced within a given context.

Keywords: Entrepreneurial ability; perception; self-confidence; entrepreneurial context; Catalonia

\section{Springer}

(c) 2015 Bayon et al.; licensee Springer. This is an Open Access article distributed under the terms of the Creative Commons Attribution License (http://creativecommons.org/licenses/by/4.0), which permits unrestricted use, distribution, and reproduction in any medium, provided the original work is properly credited. 


\section{Background}

The pursuit of entrepreneurship requires individuals to undertake concrete actions in terms of initiating and performing activities related to new venture creation. A number of cognitions have been found to influence this action, for instance, the perception of risk (Simon et al. 2000; Forlani and Mullins, 2000), the perception of opportunity (Shane and Venkataraman, 2000; Sarasvathy et al. 2005; Arenius and Minniti, 2005), and the perception of entrepreneurial ability (Shapero and Sokol, 1982; Arenius and Minniti, 2005). Such evidence has resulted in a cognitive school of thought that emphasizes the distinctiveness of cognitive attributes that makes entrepreneurial cognition different from the rest of the population (Krueger, 2005; Mitchell et al. 2007, Grégoire et al. 2011). However, most studies focus on the consequence of entrepreneurial cognition ignoring the pre-founding factors that may condition the influence of cognitive factors on the decision to initiate nascent entrepreneurial activities (Grégoire et al. 2011). In this paper we examine the prefounding factors that influence one such cognition, the positive perception of one's entrepreneurial ability.

Understanding the antecedents of perceived entrepreneurial ability is important as it can lead to the source of an important cognitive attribute that has a significantly positive influence on nascent entrepreneurial activity (Arenius and Minniti, 2005; Townsend et al. 2010; Clercq et al. 2011; Bayon et al., 2015). Moreover, although perceived entrepreneurial ability is similar to entrepreneurial self-efficacy there is an important difference. Unlike perceived entrepreneurial ability, entrepreneurial self-efficacy is an indication of two different and distinct ability beliefs - the first is specific or task related confidence, for instance, the ability to perform the various tasks related to new venture creation and the other is the confidence that such task-related abilities would lead to a successful outcome, for instance, successful creation of a new venture (Wood and Bandera, 1989; McGee et al. 2009). Townsend et al. (2010) has shown that task related perceptions such as perceived entrepreneurial ability can exist independently of goal attainment beliefs (Townsend et al. 2010). If so, and together with the finding that perceived entrepreneurial ability influences nascent entrepreneurial activity it is necessary to identify the root cause of an important antecedent of nascent entrepreneurial activity (Grégoire et al. 2011).

The specific objective of our study is to examine the role of individual level factors and the external context in influencing perceived entrepreneurial ability. We suggest that perceived entrepreneurial ability arises not only from human capital factors such as education and experience but also from the learning gained by being situated in a given context. This context which we call the entrepreneurial context such as entrepreneurial role models (Bikhchandani et al. 1998; Gibson, 2004; Vaillant and Lafuente, 2007; Bosma et al. 2012) and territorial region (Lafuente et al. 2007; Lafuente et al. 2010) increases individuals' awareness of their entrepreneurial abilities. We ground our conceptual framework on the social cognition theory (Bandura, 2001) to argue that signals, through direct participation in learning as well as observational learning influences positive perceptions of entrepreneurial ability.

Our empirical setting is Catalonia, a province in the North-east of Spain which unlike the rest of Spain has a strong entrepreneurial heritage (Lafuente et al., 2007; Lafuente et al., 2010). In 2010, Catalonia, like the rest of Southern Europe was gripped by a strong economic crisis. The high unemployment that followed needed renewed emphasis 
on exploring avenues to identify untapped sources of economic growth. By identifying the antecedents of perceived entrepreneurial ability we contribute to policy making efforts that seeks to increase regional rate of entrepreneurship.

The rest of the paper is organized as follows. In the next section we explain how socially acquired cognition influences perceived entrepreneurial ability followed by hypotheses about how individual level factors and the entrepreneurial context influences perceived entrepreneurial ability. This is followed by a discussion on the the methods used to test our hypotheses and the results/discussion and conclusions.

\section{Perception of entrepreneurial ability}

Literally perception means the act or faculty of apprehending by means of the senses or the mind. Mental perceptions is a specific form of cognition, the latter referring to all processes by which sensory input is transformed, reduced, elaborated, stored, recovered, and used (Neisser, 1967). Mental perceptions a lead to mental models, the causal inferences developed by individuals to represent real, imaginary or hypothetical situations (Johnson-Laird, 1983). Mental models continuously guide an individual's understanding of reality when new information/data from the external information is received (Mitchell et al. 2011) However, the new information and the way it is mentally represented or perceived (mental models) do not necessarily lead to behaviour execution. The cognitive learning theory argues that a new mental model induced by perception may remain dormant until signals in the form of information cues for behaviour execution are received (Bandura, 1989, 2001). In the reciprocal causation model of behaviour, Bandura (1989) suggests that the external environment, personal factors and previous behavioural experiences provide information cues that create heightened awareness or understanding of the information through perception (Pomerantz, 2003).

Of all perceptions entrepreneurial perception is related to mental representation ${ }^{\mathrm{b}}$ of entrepreneurship or what individuals think about entrepreneurship (Palich and Bagby, 1995; Liñán et al. 2011). This mental representation could be related to the different aspects of the entrepreneurial process. For example consider opportunity discovery wherein individuals develop heightened awareness ("alertness") of arbitrage situations for profit making (Kirzner, 1979; Sarasvathy et al. 2005). In a similar way while addressing the risks of venturing entrepreneurs tend to frame information in a way that tends to lower its magnitude that it actually is (Simon et al. 2000; Forlani and Mullins, 2000; Douglas, 2006). Krueger and Carsrud (1993) suggested that while developing entrepreneurial intentions individuals frame information about entrepreneurship in terms of feasibility and desirability of an entrepreneurial career ${ }^{\mathrm{c}}$ (Krueger et al. 2000).

Considering the importance of information and information cues in triggering specific perceptions, individual's prior as well as current information becomes important in the development of ability perceptions (Shane, 2000; Ucbasaran et al. 2008; Nanda and Sorensen, 2010). While human capital investments in education and training provides prior private information to compare one's ability for the task of new venture creation, the external environment provides current information about the feasibility of task execution (Mitchell et al. 2011). For instance, by observing others' behaviour, attitude and behavioural outcomes individuals obtain the information necessary for determining task feasibility (Bandura, 1977). This way the external environment represents a 
source of public information that could provide the information cues for the formation of specific perceptions. Therefore, one's prior information together with an environment with thick information pertaining to entrepreneurship provide the base necessary for forming favourable or unfavourable perception of entrepreneurial ability. In the next section we derive hypothesis about how individual's prior experiences through human capital investments could lead to perceived entrepreneurial ability.

\section{Individual level factors and perceived entrepreneurial ability: The role of human capital}

Human capital has been defined as the knowledge, skills and experience of individuals (Becker, 1993). In this paper ability is used to suggest the application of knowledge, skills and experience to particular ends i.e. ability in a particular domain is the use of knowledge, skills and experience to execute tasks related to that domain. For instance, when a medical student using his knowledge, skills and experience of medical science treats (attends to his patient) his patients he has the ability to make use of his knowledge, skills and experience acquired through medical education and training ${ }^{\mathrm{d}}$.

According to the human capital theory abilities are acquired through formal education and on-the job training (Becker, 1993). Formal education and on-the-job training are individual-level resources that provide access to private information. Becker (1993) suggests that formal education leads to two types of abilities, general ability and specific ability. General abilities are those that can be applied across tasks or knowledge domains. They are an indication of the breadth of knowledge and skills while specific ability indicates depth. General ability enhances individual's cognitive abilities through declarative knowledge or "what to do" (Cauley 1986). In addition, it helps in 1) the retention of information (Conway et al. 1991) 2) application of acquired information outside classroom situations (Cole et al. 1976 3) the development of general problem solving capacity (Husen and Juijnman, 1991).

One particular aspect of increased level of formal education is its relationship with cognitive ability. Progressively, higher levels of formal education lead to greater levels of cognitive ability (Falch and Massih, 2011). For instance, individuals with secondary education are more likely to have more cognitive ability over someone with just basic/ primary education. This would indicate a greater ability to perceive one's ability with higher levels of education, with individuals at tertiary levels of education having the highest cognitive ability. However, higher levels of education also lead to specialization. Specialization is the increase in the depth of knowledge and skills in specific knowledge domains. Specialized knowledge and skills as an indicator of academic intelligence is essential for professional success but not necessarily important for undertaking the diverse tasks (breadth) involved in entrepreneurship (Sternberg, 2004; Lazear, 2005; Lechmann and Schnabel, 2014). Moreover, higher level of knowledge or specialization could make individuals underestimate their abilities (Kruger and Dunning, 1999) and/or could make them more realistic in assessing their abilities (Hartog et al., 2010). Therefore, we suggest that higher level of education will be positively associated with favorable perception of entrepreneurial ability, except at the highest level.

H1: There is a positive relationship between the level of education and perceived entrepreneurial ability except at the highest level.

Unlike general ability acquired through formal education, specific abilities are acquired through on-the-job experience (Becker, 1993). On the job experience provides 
individuals procedural information or "how to perform a given task" (Cauley 1986). Procedural information facilitates learning by doing (Kolb, 1984). Furthermore, job experience provides access to tacit information (Davidsson and Honig, 2003). Moreover, it provides a reference point necessary for evaluation of one's ability in occupations and whether those can be transferred to entrepreneurship (Nanda and Sorensen, 2010). For instance, individuals with multiple job roles are more likely to be equipped with a diversity of information that could be useful in entrepreneurship (Unger et al. 2011). Therefore, we suggest that,

H2: Individuals with job experience are more likely to have positive perceptions of their entrepreneurial ability than those who do not have job experience.

Although formal education and experience provide information to assess one's entrepreneurial abilities to different degrees, entrepreneurship requires task specific abilities (Unger et al. 2011). For instance, individuals need to know about customers' problems, about the way the market works, how to mobilize new venture resources and so on. Such task specific information can be obtained formally through entrepreneurship training. In addition to gaining declarative information about business activities, participation in entrepreneurship training enables individuals to evaluate their entrepreneurial aptitude (Von Graevenitz et al. 2010). Entrepreneurship training improves entrepreneurial cognition (Duening 2008) and enhances favourable perception of one's entrepreneurial ability (Peterman and Kennedy, 2003). Such perceptions are further strengthened through direct exposure to venture creating experience, either through own effort or through family business (Dunn and Holtz-Eakin, 2000). For instance, prior entrepreneurial experience helps in developing better judgments (Gruber et al. 2012). Better judgment make individuals more realistic (Koellinger et al. 2007), improves individual's predictive abilities (Cassar, 2014) and realism in comprehending the tasks related to new venture creation and management (Dimov, 2010). We suggest that individuals are more likely to develop positive perceptions about their entrepreneurial abilities when they have formal training in entrepreneurship or prior entrepreneurial experience.

H3a: Individuals with task-specific abilities through entrepreneurship training are more likely to develop positive perceptions of their entrepreneurial ability.

H3b: Individuals with task-specific abilities through prior entrepreneurship experience are more likely to develop positive perceptions of their entrepreneurial ability.

Gender has significant influence on perceptions of entrepreneurial ability. Empirical evidence in this regard suggests that females are less likely to develop positive perceptions of entrepreneurial ability (Thébaud 2010; Kelley et al. 2013). This could be due to way females create mental models of entrepreneurship. For instance, females are more likely to perceive entrepreneurship as masculine (Gupta et al. 2009), thus inhibiting a positive association between their own abilities for entrepreneurship. This could be exacerbated by the lack of female entrepreneurial role models (Driga et al. 2009). Secondly, by having lower preference for entrepreneurship as a career females are less inclined towards learning or observing information related to the task of entrepreneurship. This could influence perception about their own ability to become an entrepreneur (Verheul et al. 2012). Therefore we hypothesize that,

H4: Females are less likely to develop positive perceptions of their entrepreneurial ability compared to males. 
Age could influence perceived entrepreneurial ability through interpretation of received information. For instance, low meta-cognitive ability due to inexperience could lead younger individuals to develop an over-estimation bias and hence positive perception of their entrepreneurial abilities (Kruger and Dunning, 1999), unlike older individuals whose lack of task related experience (prior entrepreneurship or entrepreneurship training) could lead to a more realistic assessment of their entrepreneurial ability (Fraser and Greene, 2006). Hence,

H5a: Younger individuals are more likely to develop positive perception of their entrepreneurial ability compared to older individuals.

Moreover, considering that females in general tend to be more underconfident about their entrepreneurial abilities than their male counterparts, we suggest that age would not have any effect on the positive perceptions of entrepreneurial ability among females. Therefore, we hypothesize that,

H5b: Females irrespective of their age are less likely to have positive perception of their entrepreneurial abilities.

\section{The entrepreneurial context and perceived entrepreneurial ability}

The entrepreneurial context can serve as a frame of reference for comparing entrepreneurial abilities and perceiving the feasibility of an entrepreneurial career. For instance, individuals who have personal information of other entrepreneurs might be more aware of the role requirement of entrepreneurship. This facilitates the comparison of one's own ability for entrepreneurship. According to Bandura (1977) knowing other entrepreneurs not only provide a source of information for entrepreneurship but also substantiates the information already learnt through formal sources by providing real evidence. For instance, other entrepreneurs provide the evidence that entrepreneurship could be a viable career option (Vaillant and Lafuente, 2007). Bosma et al. (2012) suggest that information about other entrepreneurs as a source of observational learning perform four inter-related functions. They create awareness about the given behavior (Gibson, 2004), function as a source of inspiration and motivation for executing the given behavior (Lockwood et al. 2004), provide guidelines for action (Gibson, 2004) and are a possible source of support and guidance during behavior execution (Nauta and Kokaly 2001). In addition, knowing other entrepreneurs changes attitudes and beliefs about a person's perceived ability to be successful in a new venture (Auken et al. 2006). As such we suggest that those who have knowledge of other entrepreneurs are more likely to develop positive perception of entrepreneurial ability. Such positive perceptions are likely to be strengthened in the presence of entrepreneurship training becasue of an individuals' ability to correlate the knowledge gained from entrepreneurship training and its application through personal knowledge of other entrepreneurs.

H6a: Individuals who personally knows other entrepreneurs are more likely develop positive perceptions of entrepreneurial ability.

H6b: The joint effect of personal knowledge of other entrepreneurs and entrepreneurship training is likely to be positive.

In addition to observational learning from human actors, regions act as a source of information about entrepreneurship (Florida, 1995; Lambooy, 2002). Individuals are more likely to gain information related to entrepreneurship when they reside in regions where entrepreneurship is considered a viable career option (Vaillant and Lafuente, 
2007). In this regard, urban agglomerations provide ideal ground for accessing information related to entrepreneurship. For instance, information about other entrepreneurs, about venture resource suppliers like venture capitalists and institutions that facilitate trade and commerce are easier to find in urban compared to rural regions (Florida, 2005). Secondly, employment opportunities in urban agglomerations provide a source of obtaining experiential learning (Gabe and Abel, 2011) that could be useful in assessing ones' entrepreneurial abilities. We argue that because individuals also learn through behavioural modelling (Bandura, 1977), urban agglomerations provide the entrepreneurial context for forming perceptions about entrepreneurial abilities. In such regions individuals not only have greater number of sources to acquire relevant information about entrepreneurship by direct participation but also reference points because of greater density of entrepreneurs and framework conditions (Reynolds et al. 2005). We suggest that the combined effect of entrepreneurship training and urban location will amplify the positive perception of one's entrepreneurial ability. Therefore we hypothesize,

H7a: Individuals in urban regions are more likely to develop positive perceptions of their entrepreneurial ability.

H7b: The joint effect of entrepreneurship training and territory is likely to be significantly positive.

\section{Method}

The empirical estimation of the model is done using data from the Global entrepreneurship Monitor (GEM) database. The data used for this particular study was collected in the Catalonia autonomous region of Spain between the month May and July, 2010 through telephone surveys. After removing the missing values, from an initial sample of 2000 randomly selected individuals between the age group of 18-64 years the final sample used for this study contains 1961 respondents. The selected sample can be divided into three groups: Nascent entrepreneurs (those who are in the process of creating a new venture), Owner-managers of existing business and non-entrepreneurs (rest of the sample). It is possible that because of involvement in business creation and/or management activities, the respondent in the first two groups are more likely to respond favourably to the dependent variable (perceived entrepreneurial ability) compared to the rest of the sample. We control for this potential bias by using business status of the respondents (whether they are nascent entrepreneurs, owner mangers or non-entrepreneurs) as dummies in our analytical model.

Dependent Variable: The dependent variable perceived entrepreneurial ability in this study is a self-reported dichotomous measure in which the independent random sample of working age adults was asked "Do you have the knowledge, skills and experience to start a new business". As mentioned earlier the measure of perceived entrepreneurial ability used in this study is different from entrepreneurial self-efficacy. While entrepreneurial self-efficacy measures both perception of entrepreneurial ability and the perception of entrepreneurial success (McGee et al. 2009), our measure captures only one aspect of this construct, namely the perception or self-confidence in one's entrepreneurial ability (Townsend et al. 2010). In our sample 53.9\% of the respondents have positive perception of their entrepreneurial ability. Such high level of perceived entrepreneurial ability when dealing with complex tasks like new venture creation may seem 
surprising. This could be an indication of espoused value rather than theories-in-use (Argyris, 1991). It could also be due to the entrepreneurial culture that exist in the Catalonia region of Spain (Lafuente et al. 2007; Lafuente et al. 2010).

Independent variables: General ability is measured using respondent's completed level of formal education divided into six categories: Basic education (Education below secondary level), secondary education, post-secondary (Vocational), post-secondary (Low Bachelor), post-secondary (high Bachelor), post-secondary (graduate studies). Previous studies has used similar indicator to measure general ability (Davidsson and Honig, 2003; Vaillant and Lafuente, 2007). From Table 1 it can be seen that there is a significant difference in perceived entrepreneurial ability across the three lower categories of post-secondary education i.e. Post Secondary (Vocational), Post secondary (Low Bachelor) and Post Secondary (High Bachelor). It should be noted that the mean difference between those who have positive perceptions of entrepreneurial ability and those who do not for secondary education and post secondary (Graduate studies) categories is not significant.

Job experience is nominal variable measured through job status at the time of survey. This variable comprises 1) those who are working (WORKING) 2) Not-Working (unemployed or looking for employment) 3) Not working because they are students, retired or disabled (Refer to Table 2 for the terminology and coding used). Table 1 show that the proportion of respondents working at the time of survey who have positive perceptions of their entrepreneurial ability (73.98\%) is significantly higher than those without perceived entrepreneurial ability (53.87\%). Interestingly, for respondents in the other categories of job experience the mean value of those with positive perceptions of entrepreneurial ability is lower compared to those who lack perceived entrepreneurial ability and this difference is significant for both the job categories.

Task specific ability is measured using entrepreneurship related training and prior experience in creating a new venture (prior entrepreneurial experience). In the sample, the proportion of respondents with entrepreneurship training (36.8\%), and prior entrepreneurial experience $(26.68 \%)$ is significantly higher among individuals with perceived entrepreneurial ability compared to those with negative perceptions of entrepreneurial ability (10.84\% and $10.29 \%$ respectively) (Table 1$)$.

The entrepreneurial context is measured using two questionnaire items, 1) whether the respondents "know someone personally who started a business in the past two years". 2) Recoding the territory where the respondent resided (urban/rural as indicated in the in the Table above). From Table 1 it can be seen that the proportion of respondents with perceived entrepreneurial ability who personally know other entrepreneurs (39.07\%) is significantly higher than the figure observed for the sub-sample of individuals without perceived entrepreneurial ability (22.23\%). However, there is no significant difference in perceived entrepreneurial ability between respondents from urban and rural regions.

We also consider the effect that current business ownership (owner-manager) or pursuit of nascent entrepreneurial activities of the respondent (nascent entrepreneur) might have on one's positive perception of entrepreneurial abilities by segregating non-entrepreneurs from owner-mangers and nascent entrepreneurs using dummies.

To examine the influence of the proposed explanatory variables on perceived entrepreneurial ability a logit regression model is used (Greene, 2003). In a logit model the dependent variable is determined in terms of probability. As such the probability of 
Table 1 Descriptive statistics of the determinants of perceived entrepreneurial ability

\begin{tabular}{|c|c|c|c|c|}
\hline & $\begin{array}{l}\text { Perceived } \\
\text { entrepreneurial } \\
\text { ability }\end{array}$ & $\begin{array}{l}\text { Without perceived } \\
\text { entrepreneurial ability }\end{array}$ & Overall & $\begin{array}{l}\text { Kruskal-Wallis } \\
\text { chi square }\end{array}$ \\
\hline \multirow[t]{2}{*}{ Non-entrepreneurs } & 0.7464 & 0.9690 & 0.8490 & $188.245^{* * *}$ \\
\hline & $(0.4352)$ & $(0.1733)$ & $(0.3580)$ & \\
\hline \multirow[t]{2}{*}{ Nascent entrepreneurs } & 0.0378 & .0022 & .02141 & $29.497^{* * *}$ \\
\hline & (0.1909) & $(0.0470)$ & $(0.1448)$ & \\
\hline \multirow[t]{2}{*}{ Owner managers } & 0.2175 & 0.0287 & 0.1305 & $153.004^{* * *}$ \\
\hline & $(0.4128)$ & $(0.1672)$ & $(0.3369)$ & \\
\hline \multirow[t]{2}{*}{ Age (in years) } & 43.7691 & 44.0685 & 43.9071 & $0.5448+$ \\
\hline & $(11.3976)$ & $(12.9383)$ & (12.1299) & \\
\hline \multirow[t]{2}{*}{ Gender ( 1 for female) } & 0.4314 & 0.5608 & 0.4910 & $32.645^{* * *}$ \\
\hline & $(0.4955)$ & $(0.4965)$ & $(0.5000)$ & \\
\hline \multirow[t]{2}{*}{ Basic education } & 0.3907 & 0.5188 & 0.4497 & $32.282 * * *$ \\
\hline & $(0.4881)$ & (0.4999) & $(0.4975)$ & \\
\hline \multirow[t]{2}{*}{ Secondary education } & 0.1050 & 0.1073 & 0.1060 & 0.026 \\
\hline & $(.3067)$ & (0.3096) & $(0.3080)$ & \\
\hline \multirow{2}{*}{$\begin{array}{l}\text { Post secondary education } \\
\text { (Vocational education) }\end{array}$} & 0.1996 & 0.1659 & 0.1840 & $3.681^{*}$ \\
\hline & (0.3999) & $(0.3722)$ & $(0.3876)$ & \\
\hline \multirow{2}{*}{$\begin{array}{l}\text { Post secondary education } \\
\text { (Low Bachelors) }\end{array}$} & 0.1797 & 0.1238 & 0.1540 & $11.664^{* * *}$ \\
\hline & $(0.3841)$ & $(0.3296)$ & $(0.3610)$ & \\
\hline \multirow{2}{*}{$\begin{array}{l}\text { Post secondary education } \\
\text { (High Bachelors) }\end{array}$} & 0.1059 & 0.0707 & 0.0897 & $7.372^{* * *}$ \\
\hline & $(0.3079)$ & $(0.2566)$ & $(0.2858)$ & \\
\hline \multirow{2}{*}{$\begin{array}{l}\text { Post secondary education } \\
\text { (Graduate experience) }\end{array}$} & 0.0189 & 0.0132 & 0.0163 & 0.968 \\
\hline & $(0.1363)$ & $(0.1145)$ & $(0.1267)$ & \\
\hline \multirow{2}{*}{$\begin{array}{l}\text { Working (full time or } \\
\text { part-time) }\end{array}$} & 0.7398 & 0.5387 & 0.6471 & $86.261^{* * *}$ \\
\hline & $(0.4389)$ & $(0.4987)$ & $(0.4779)$ & \\
\hline \multirow[t]{2}{*}{ Not working (Unemployed) } & 0.1854 & 0.3019 & 0.2391 & $36.363^{* * *}$ \\
\hline & $(0.3888)$ & $(0.4593)$ & $(0.4266)$ & \\
\hline \multirow{2}{*}{$\begin{array}{l}\text { Not Working (Students, } \\
\text { retired, disabled etc.) }\end{array}$} & 0.0747 & 0.1592 & 0.1137 & $34.546^{* * *}$ \\
\hline & $(0.2630)$ & $(0.3661)$ & $(0.3175)$ & \\
\hline \multirow[t]{2}{*}{ Entrepreneurship training } & 0.3680 & 0.1084 & 0.2483 & $175.847^{* * *}$ \\
\hline & $(0.4825)$ & $(0.3111)$ & $(0.4322)$ & \\
\hline \multirow{2}{*}{$\begin{array}{l}\text { Prior entrepreneurial } \\
\text { Experience }\end{array}$} & 0.2668 & 0.1029 & 0.1912 & $84.608 * * *$ \\
\hline & $(0.4425)$ & $(0.304)$ & $(0.3934)$ & \\
\hline \multirow{2}{*}{$\begin{array}{l}\text { Knowledge of other } \\
\text { entrepreneurs }\end{array}$} & 0.3907 & 0.2223 & 0.3131 & $64.204^{* * *}$ \\
\hline & $(0.4881)$ & $(0.4161)$ & $(0.4639)$ & \\
\hline \multirow[t]{2}{*}{ Territory (1 for urban) } & 0.8061 & 0.8197 & 0.8123 & 0.594 \\
\hline & $(0.3956)$ & $(0.3847)$ & $(0.3905)$ & \\
\hline Number of cases & 1057 & 904 & 1961 & \\
\hline
\end{tabular}

Standard deviation is presented in brackets. ${ }^{*}{ }^{* * *}=$ significant at the $10 \%, 5 \%$ and $1 \%$ respectively.

+ T-statistic.

perceived entrepreneurial ability $\left(\operatorname{Pr}\left(Y_{i}=1\right)=\hat{p}_{i}\right)$ is modeled as a function of the aforementioned set of independent variables $\left(X_{i}\right)$, where $\hat{p}_{i}$ is expressed as $\hat{p}_{i}=e^{X_{i} \beta_{j}} / 1+e^{X_{i} \beta_{j}}$, and parameters $\left(\beta_{j}\right)$ are estimated by maximum likelihood method. 
Table 2 Terminology, Coding and Variable Description

\begin{tabular}{|c|c|c|c|c|}
\hline Variable & $\begin{array}{l}\text { GEM } \\
\text { variable }\end{array}$ & Questionnaire Item & $\begin{array}{l}\text { Response code } \\
\text { (Original GEM } \\
\text { coding) }\end{array}$ & $\begin{array}{l}\text { Terminology and } \\
\text { Coding used\#\#\# }\end{array}$ \\
\hline \multirow{2}{*}{$\begin{array}{l}\text { Perceived } \\
\text { Entrepreneurial Ability } \\
\text { (Dependent variable) }\end{array}$} & \multirow[t]{2}{*}{ SUSKILL } & \multirow{2}{*}{$\begin{array}{l}\text { "Do you have the knowledge, } \\
\text { skills and experience to start a } \\
\text { new business" }\end{array}$} & Yes $=1$ & Yes $=1$ \\
\hline & & & $\mathrm{No}=0$ & $\mathrm{No}=0$ \\
\hline \multicolumn{5}{|c|}{ Independent Variable(s) (Individual Level factors) } \\
\hline \multirow[t]{6}{*}{ Education\# } & \multirow[t]{6}{*}{ GEMEDUC } & \multirow[t]{6}{*}{$\begin{array}{l}\text { "What is the highest level of } \\
\text { education you have completed?" }\end{array}$} & $0=$ None & $\begin{aligned} 1= & \text { Basic } \\
& \text { Education }\end{aligned}$ \\
\hline & & & $\begin{array}{l}1=\text { Some } \\
\text { Secondary }\end{array}$ & $\begin{aligned} 2= & \text { Secondary } \\
& \text { Education }\end{aligned}$ \\
\hline & & & $2=$ Secondary & $\begin{aligned} 3= & \text { Post } \\
& \text { Secondary } \\
& \text { education } \\
& \text { (Vocational) }\end{aligned}$ \\
\hline & & & $\begin{aligned} 3= & \text { Post } \\
& \text { Secondary }\end{aligned}$ & $\begin{aligned} 4= & \text { Post } \\
& \text { Secondary } \\
& \text { education } \\
& \text { (Low Bachelor) }\end{aligned}$ \\
\hline & & & $4=$ Graduate & $\begin{aligned} 5= & \text { Post } \\
& \text { Secondary } \\
& \text { education } \\
& \text { (High } \\
& \text { Bachelor) }\end{aligned}$ \\
\hline & & & & $\begin{aligned} 6= & \text { Post } \\
& \text { Secondary } \\
& \text { (Graduate } \\
& \text { studies) }\end{aligned}$ \\
\hline \multirow[t]{3}{*}{ Job Status\#\# } & \multirow[t]{3}{*}{ GEMWORK3 } & \multirow[t]{3}{*}{$\begin{array}{l}\text { GEM Harmonized work in } 3 \\
\text { categories }\end{array}$} & $\begin{aligned} 10= & \text { Working (full } \\
& \text { or part time) }\end{aligned}$ & $\begin{aligned} 1= & \text { Working } \\
& \quad \text { Full or part) }\end{aligned}$ \\
\hline & & & $\begin{aligned} 20= & \text { Not Working } \\
& \text { (looking for } \\
& \text { employment) }\end{aligned}$ & $\begin{aligned} 2= & \text { Not Working } \\
& \text { (Unemployed) }\end{aligned}$ \\
\hline & & & $\begin{aligned} 30= & \text { Not working } \\
& \text { (students, } \\
& \text { retired, } \\
& \text { disabled) }\end{aligned}$ & $\begin{aligned} 3= & \text { Not Working } \\
& \text { (Students, } \\
& \text { retired, } \\
& \text { disabled) }\end{aligned}$ \\
\hline \multirow{2}{*}{$\begin{array}{l}\text { Entrepreneurship } \\
\text { Training }\end{array}$} & \multirow[t]{2}{*}{ ESaps5 } & \multirow{2}{*}{$\begin{array}{l}\text { "Do you consider you have } \\
\text { received some training related to } \\
\text { starting an enterprise" }\end{array}$} & $1=$ Yes & $1=$ Yes \\
\hline & & & $2=$ No & $0=\mathrm{No}$ \\
\hline \multirow{2}{*}{$\begin{array}{l}\text { Prior Entrepreneurial } \\
\text { Experience }\end{array}$} & \multirow[t]{2}{*}{ ESaps9 } & \multirow{2}{*}{$\begin{array}{l}\text { "Have you been an Entrepreneur } \\
\text { in the past?" }\end{array}$} & $1=$ Yes & $1=$ Yes \\
\hline & & & $2=$ No & $0=\mathrm{No}$ \\
\hline \multicolumn{5}{|c|}{ Independent variable(s) (Entrepreneurial Context) } \\
\hline \multirow{2}{*}{$\begin{array}{l}\text { Personal knowledge } \\
\text { of other } \\
\text { entrepreneurs }\end{array}$} & \multirow[t]{2}{*}{ knowen } & \multirow{2}{*}{$\begin{array}{l}\text { "Do you know someone personally } \\
\text { who started a business in the past } \\
\text { two years" }\end{array}$} & $1=$ Yes & $1=$ Yes \\
\hline & & & $0=$ No & $0=\mathrm{No}$ \\
\hline \multirow[t]{2}{*}{ Territory } & \multirow[t]{2}{*}{ esstrata } & \multirow[t]{2}{*}{ UrbancpsRural } & $1=$ Urban & $1=$ Urban \\
\hline & & & $2=$ Rural & $0=$ Rural \\
\hline
\end{tabular}

\# Note that this variable is the harmonized education variable of GEM. In the original dataset for Catalonia (variable: esreduc), this variable captures more detailed information about the completed level of education of the respondents. The final categorization (the last column) is based on the esreduc variable in the Catalonia GEM dataset for 2010. \#\# Note that we use the harmonized GEM variable for measuring the job status ( 3 categories) from the original variable occu which is in 8 categories.

\#\#\# All variables in coded as dummy for analysis.

\section{Results and discussion}

Our estimation strategy is as follows 1) first we estimate models containing only the direct effect of the independent variables and assess model fit using LR Chi square 
statistics (also note the Homer and Lemeshow chi square goodness of fit in the Table 3). This is shown in Table 3 where Model 1 displays the coefficients of logistic regression of only the individual level explanatory variables, followed by model 2 that display variables related to the entrepreneurial context while model 3 shows the effect of both individual level and contextual variables. The corresponding marginal effects are shown in Table 4. 2) Second, we estimate model 4 containing direct and interaction terms of gender with age, entrepreneurship training with the contextual variables (terrirory and personal knowledge of other entrepreneurs).

The Log likelihood ratio test (LR) between model 1 and model 3 suggests that including the variables related to entrepreneurial context results in statistically significantly improvement in model fit ${ }^{\mathrm{e}}\left(v^{2}(2)=21.96 \mathrm{p}<0.0000\right)$. Including the individual-level factors in model 2 also significantly improves the statistical fit $\left(v^{2}(9)=245.54\right.$, $\mathrm{p}<0.0000$ ) of the model that contains both entrepreneurial context and individual-level factors (model 3). Model 4 that contains the interaction terms also improves the goodness of fit over model $1\left(v^{2}=38.38, \mathrm{p}<0.0000\right)$ as well as model $2\left(v^{2}=261.96\right.$, $\mathrm{p}<0.0000)$ and model $3\left(v^{2}=16.43, \mathrm{p}<0.0000\right)$.

As far as findings related to the individual variables are concerned we find that age is significantly related to positive perceptions of entrepreneurial ability (model 4 coefficient, Table 3) suggesting the perceived entrepreneurial ability in Catalonia increases with age. This is contrary to our hypothesis H5a. We also find that the effect of gender on perceived entrepreneurial ability in the Catalonia region of Spain is significantly negative (model 1 and model 3 coefficients). However, this effect does not persist in model 4 . This is due to the moderation that age have on gender (Model 4 coefficient of interaction term between gender and age is significantly negative) suggesting with increasing age females in Catalonia are less likely to have positive perceptions of their entrepreneurial ability. Thus, we do not find support for our hypothesis H5b.

Among the education variables secondary education does not have any effect on perceived entrepreneurial ability with respect to the reference category of basic education. Similarly, among the different post secondary education categories we find that the lowest (vocational) and the highest (graduate studies) do not have any effect on favorable perceptions of entrepreneurial ability. However, the median categories, post secondary (Low bachelor) and post secondary (high bachelor) has a significantly positive effect on favorable perception of entrepreneurial ability. If we compare the level of significance and the marginal effect (Table 4, model 4), we find that with increasing levels of education (from secondary to post secondary), positive perception of entrepreneurial ability increases at first $(11.26 \%$ change from basic education to post secondary (low bachelor) at $\mathrm{p}<0.00)$ and then decreases $(9.42 \%$ change from basic education to post secondary (high bachelor) at $\mathrm{p}<0.05$ ). This result supports our hypothesis $\mathrm{H} 1$ that although there is a positive relationship between the level of education and perceived entrepreneurial ability, the impact of education on perceived entrepreneurial ability is greatest at the median level of education and decreases with further increase in education. It should be noted that the above results could be influenced by the fact that in 2010 Catalonia was in the middle of the economic crisis and for several years the local government have been spreading entrepreneurship concepts and pushing people towards developing an entrepreneurial orientation. Therefore in Catalonia it is possible that these factors have some influence in our result. For instance, the limited labor 
Table 3 Logistic Regression of perceived entrepreneurial ability

\begin{tabular}{|c|c|c|c|c|}
\hline VARIABLES & MODEL 1 & MODEL 2 & MODEL 3 & MODEL 4 \\
\hline \multirow[t]{2}{*}{ Nascent entrepreneur } & $2.7593^{* * *}$ & $2.866^{* * *}$ & $2.6309^{* * *}$ & $2.6691^{* * *}$ \\
\hline & $(0.7358)$ & $(0.7180)$ & $(0.7173)$ & $(0.7001)$ \\
\hline \multirow[t]{2}{*}{ Owner manager } & $1.8920^{* * *}$ & $2.2492^{* * *}$ & $1.8645^{* * *}$ & $1.8466^{* * *}$ \\
\hline & $(0.2270)$ & $(0.2143)$ & $(0.2270)$ & $(0.2270)$ \\
\hline \multirow[t]{2}{*}{ Age (in years) } & 0.0018 & & 0.0044 & $0.0157^{* * *}$ \\
\hline & $(0.0044)$ & & $(0.0044)$ & $(0.0059)$ \\
\hline \multirow[t]{2}{*}{ Gender (1for female) } & $-0.4420^{* * *}$ & & $-0.4328^{* * *}$ & 0.5773 \\
\hline & $(0.1063)$ & & $(0.1068)$ & $(0.3899)$ \\
\hline \multirow[t]{2}{*}{ Secondary education } & 0.1891 & & 0.1990 & 0.2268 \\
\hline & $(0.1765)$ & & $(0.1778)$ & $(0.1779)$ \\
\hline \multirow[t]{2}{*}{ Post Secondary (vocational) } & 0.1759 & & 0.2135 & 0.2213 \\
\hline & $(0.1461)$ & & $(0.1479)$ & $(0.1487)$ \\
\hline \multirow[t]{2}{*}{ Post Secondary (low Bachelors ) } & $.4836^{* * *}$ & & $0.4941^{* * *}$ & $0.4791^{* * *}$ \\
\hline & $(.1577)$ & & $(0.1590)$ & $(0.1606)$ \\
\hline \multirow[t]{2}{*}{ Post Secondary (high bachelors) } & $0.4733^{* *}$ & & $0.4267^{* *}$ & $0.4002^{* *}$ \\
\hline & $(0.1918)$ & & (0.1913) & $(0.1918)$ \\
\hline \multirow[t]{2}{*}{ Post Secondary (Graduate) } & .07350 & & 0.0055 & 0.0244 \\
\hline & $(0.4224)$ & & $(0.4413)$ & $(0.4492)$ \\
\hline \multirow[t]{2}{*}{ Working (Full or part time) } & $0.370^{* * *}$ & & $0.3205^{* * *}$ & $0.2936^{* *}$ \\
\hline & $(0.126)$ & & (0.1273) & $(0.1297)$ \\
\hline \multirow[t]{2}{*}{ Not working (sudents, retired etc.) } & $-0.448^{* *}$ & & $-0.4802^{* *}$ & $-0.4864^{* *}$ \\
\hline & $(0.182)$ & & $(0.1846)$ & $(0.1862)$ \\
\hline \multirow[t]{2}{*}{ Entrepreneurship Training } & $1.351^{* * *}$ & & $1.3251^{* * *}$ & $2.1038^{* * *}$ \\
\hline & $(0.138)$ & & $(0.1392)$ & $(0.4220)$ \\
\hline \multirow[t]{2}{*}{ Prior Entrepreneurship } & $1.103^{* * *}$ & & $1.0342^{* * *}$ & $1.0145^{* * *}$ \\
\hline & $(0.147)$ & & $(0.1496)$ & $(0.1504)$ \\
\hline \multirow[t]{2}{*}{ Knowledge of Other entrepreneurs } & & $0.7248^{* * *}$ & $0.5526^{* * *}$ & $0.6952^{* * *}$ \\
\hline & & $(0.1068)$ & $(0.1171)$ & $(0.1280)$ \\
\hline \multirow[t]{2}{*}{ Territory (1 for Urban) } & & 0.0748 & 0.0074 & 0.0737 \\
\hline & & $(0.1255)$ & $(0.1343)$ & $(0.1477)$ \\
\hline \multirow[t]{2}{*}{ Gender X Age } & & & & $-0.0230^{* * *}$ \\
\hline & & & & $(0.0086)$ \\
\hline \multirow[t]{2}{*}{ Entrepreneurship Training X Territory } & & & & -0.5904 \\
\hline & & & & $(0.4293)$ \\
\hline \multirow{2}{*}{$\begin{array}{l}\text { Entrepreneurship Trianing X knowledge of } \\
\text { other entrepreneurs }\end{array}$} & & & & $-0.7827^{* * *}$ \\
\hline & & & & $(0.2855)$ \\
\hline \multirow[t]{2}{*}{ Constant } & $-0.7384^{* * *}$ & $-0.3773^{* * *}$ & $0.9948^{* * *}$ & $-1.599^{* * *}$ \\
\hline & $(0.2469)$ & $(0.1196)$ & $(0.2796)$ & $(0.324)$ \\
\hline LR Chi (d.o.f) & $300.96(13)^{* * *}$ & $174.99(4)^{* * *}$ & $305.45(15)^{* * *}$ & $327.45(18)^{* * *}$ \\
\hline Psuedo $R^{2}$ & 0.1812 & 0.0986 & 0.1893 & 0.1953 \\
\hline Hesmer \& Lemeshow chi & 1243.37 & 5.58 & 1595.91 & 1560.52 \\
\hline Observations & 1961 & 1961 & 1961 & 1961 \\
\hline
\end{tabular}

Robust Standard Errors in parenthesis, ${ }^{* * *} p<0.01, * * p<0.05$. 
Table 4 Marginal effect of the determinants of Perceived entrepreneurial ability

\begin{tabular}{|c|c|c|c|c|}
\hline & $\mathrm{dy} / \mathrm{dx}^{++}$ & $\mathrm{dy} / \mathrm{dx}$ & $d y / d x$ & $\mathrm{dy} / \mathrm{dx}$ \\
\hline & Model:1 & Model:2 & Model:3 & Model:4 \\
\hline \multirow[t]{2}{*}{ Nascent entrepreneurs } & $0.3898^{* * *}$ & $0.4048^{* * *}$ & $0.3823^{* * *}$ & $0.3851^{* * *}$ \\
\hline & $(0.0353)$ & $(0.0328)$ & $(0.0380)$ & $(0.0363)$ \\
\hline \multirow[t]{2}{*}{ Owner Managers } & $0.3596^{* * *}$ & $0.4091^{* * *}$ & $0.3555^{* * *}$ & $0.3537^{* * *}$ \\
\hline & $(0.0276)$ & $(0.0222)$ & $(0.0280)$ & $(0.0285)$ \\
\hline \multirow[t]{2}{*}{ Age (in years) } & 0.0004 & & 0.0010 & $0.0038^{* * *}$ \\
\hline & $(0.0010)$ & & $(0.0011)$ & $(0.0014)$ \\
\hline \multirow[t]{2}{*}{ Gender ( 1 for female) } & $-0.1012^{* * *}$ & & $-0.1015^{* * *}$ & 0.1398 \\
\hline & $(0.0256)$ & & $(0.0257)$ & $(0.0931)$ \\
\hline \multirow[t]{2}{*}{ Secondary education+ } & 0.0455 & & 0.0478 & 0.0544 \\
\hline & $(0.0418)$ & & $(0.0420)$ & $(0.0418)$ \\
\hline \multirow[t]{2}{*}{ Post secondary (Vocational) } & 0.0424 & & 0.0513 & 0.0532 \\
\hline & $(.0349)$ & & $(0.0351)$ & $(0.0352)$ \\
\hline \multirow[t]{2}{*}{ Post secondary (Low Bachelor) } & $0.1137^{* * *}$ & & $0.1159^{* * *}$ & $0.1126^{* * *}$ \\
\hline & $(0.0353)$ & & $(0.0355)$ & $(0.0360)$ \\
\hline \multirow[t]{2}{*}{ Post secondary (High Bachelor) } & $0.1105^{* * *}$ & & $0.1001^{* *}$ & $0.0942^{* *}$ \\
\hline & $(0.0424)$ & & $(0.0428)$ & $(0.0432)$ \\
\hline \multirow[t]{2}{*}{ Post Secondary (Graduate studies) } & 0.0178 & & 0.0013 & 0.0055 \\
\hline & $(0.1018)$ & & $(0.1074)$ & $(0.109)$ \\
\hline \multirow[t]{2}{*}{ Working (Full time or part time) } & $0.0836^{* * *}$ & & $0.0785^{* * *}$ & $0.0796^{* *}$ \\
\hline & $(0.0318)$ & & $(0.0312)$ & $(0.0318)$ \\
\hline \multirow[t]{2}{*}{ Not working (Students, retired etc.) } & $-0.1184^{* *}$ & & $-0.1189^{* *}$ & $-0.1205^{* *}$ \\
\hline & $(0.04523)$ & & $(0.0458)$ & $(0.0462)$ \\
\hline \multirow[t]{2}{*}{ Entrepreneurship training } & $0.2961^{* * *}$ & & $0.2909^{* * *}$ & $0.4212^{* * *}$ \\
\hline & $(0.0254)$ & & $(0.0257)$ & $(0.0615)$ \\
\hline \multirow[t]{2}{*}{ Prior entrepreneurial experience } & $0.2435^{* * *}$ & & $0.2302^{* * *}$ & $0.2266^{* * *}$ \\
\hline & $(0.0279)$ & & $(0.0288)$ & $(0.0292)$ \\
\hline \multirow[t]{2}{*}{ Knowledge of other entrepreneurs } & & $0.1723^{* * *}$ & $0.1291^{* * *}$ & $0.1640^{* * *}$ \\
\hline & & $(0.0242)$ & $(0.0267)$ & $(0.0290)$ \\
\hline \multirow[t]{2}{*}{ Territory (1 for urban) } & & 0.0184 & 0.0018 & 0.0180 \\
\hline & & $(0.0310)$ & $(0.0327)$ & $(0.0362)$ \\
\hline \multirow[t]{2}{*}{ Gender X Age } & & & & $-0.0056^{* * *}$ \\
\hline & & & & $(0.0021)$ \\
\hline \multirow[t]{2}{*}{ Entrepreneurship training $X$ Territory } & & & & $-0.1932^{* * *}$ \\
\hline & & & & $(0.0687)$ \\
\hline \multirow[t]{2}{*}{ Entrepreneurship training $X$ Knowledge of other entrepreneurs } & & & & -0.1458 \\
\hline & & & & $(0.1057)$ \\
\hline
\end{tabular}

${ }^{++} \mathrm{dy} / \mathrm{dx}$ : for discrete variables $\mathrm{dy} / \mathrm{dx}$ is the change from $\mathrm{X}=0$ to $\mathrm{X}=1$, Robust Standard Errors in parenthesis, ${ }^{* * *} \mathrm{p}<0.01$, ** $\mathrm{p}<0.05$.

market opportunities coupled with the efforts of the government could lead educated individuals especially those at the median level of education to reassess their abilities for entrepreneurship.

Among the job categories individuals with positive job market status (working at the time of survey) are significantly more likely to develop positive perception of 
entrepreneurial ability compared to those who are not working (unemployed). This result supports hypothesis $\mathrm{H} 2$ that suggested that job experience has a positive impact on perceived entrepreneurial ability. Interestingly those "not working" (students, retired and disabled individuals) are significantly less likely to develop positive perception of their entrepreneurial ability compared to those who are "not working (unemployed)".

Also, results in model 4 of Table 3 corroborate that entrepreneurship training (coefficient $=2.1038, \mathrm{p}<0.0000)$ is positively related to perceived entrepreneurial ability and individuals with entrepreneurship training are 42.12 percentage points more likely to develop positive perceptions of their entrepreneurial ability relative to the probability of those who do not have entrepreneurship training (Model 4 coefficient in Table 4). This finding is in accordance with hypothesis H3a. Similarly, it can be seen that the probability of perceived entrepreneurial ability is significantly positive (Model 4, Table 3) and increases by 22.66 percentage points (Model 4 coefficients, Table 4) for those with prior entrepreneurial experience compared to those without prior entrepreneurial experience. Thus, hypothesis H3b that states that individuals with prior entrepreneurial experience are more likely to develop positive perceptions of their entrepreneurial ability is supported.

Concerning the entrepreneurial context, results in model 4 of Table 3 shows that knowing other entrepreneurs has a significantly positive impact on perceived entrepreneurial ability. In terms of magnitude the probability of developing perceived entrepreneurial ability increases 16.4 percentage points (model 4 coefficients, Table 4) for individuals who personally know other entrepreneurs, compared to the probability of individuals who do not. Thus hypothesis H6a is supported. However, the interaction effect of knowledge of other entrepreneurs and entrepreneurship training is significantly negative. This is in contrast to our hypothesis H6b. This result is similar to the worse -than-average effect exhibited by individuals in difficult and rare tasks (Kruger and Dunning, 2009). Regarding the role of territory we find that territory (urban or rural) shows no statistical significance. This result is contrary to Lafuente et al. (2007) and in essence means that individuals in rural areas of Catalonia are no less likely to develop positive perceptions of entrepreneurial ability than those residing in urban areas. Hence H7a is not supported. Similarly, the interaction effect of entrepreneurship training and territory is not statistically significant suggesting that entrepreneurial training among those living in urban territory has no effect on positive perceptions of entrepreneurial ability.

Overall our results reveal that both individual-level factors and the entrepreneurial context influences positive perception of entrepreneurial ability. However, contrary to our expectation not all individual-level factors influences perceived entrepreneurial ability. For instance, among the different levels of education, only median level of formal education is important for positive perceptions of entrepreneurial ability. The lack of significance of formal education, at the lowest and highest level, can be interpreted this way. Formal education is compulsory and mostly concerned with theoretical or declarative knowledge. While lowest level of such knowledge may not be sufficient for perceiving ones' entrepreneurial ability, the highest level could actually be detrimental for ones' self confidence especially while assessing abilities in rare and difficult tasks such as entrepreneurship (Kruger and Dunning, 2009). Similarly, although age has a positive effects on perceived entrepreneurial ability, older females are less likely to develop positive perceptions of entrepreneurial ability than younger females. The positive 
influence of job experience on perceived entrepreneurial ability suggests that job experience is useful for developing procedural knowledge that could later be transferred to an entrepreneurial career (Shane, 2000; Klepper, 2002). Similarly, the significant impact of entrepreneurship training and prior entrepreneurial experience indicates the importance of task specific training (Unger et al., 2011). Among the contextual variables the significantly positive relationship between personal knowledge of other entrepreneurs and perceived entrepreneurial ability must be interpreted cautiously. Personal knowledge of other entrepreneurs could promote the 'herd mentality', in which individuals choose a vocational path considered in vogue (Nanda and Sorensen, 2010). The absence of territorial influence on perceived entrepreneurial ability is an indication that perceptual indictors of ability are more "individual-centered". In other words, it does not matter if an individual lives in rural or urban region for positive perceptions of entrepreneurial ability to develop. Other factors that could explain this result is the high level of urbanization in Catalonia, one that does not provide any advantage to such urban territories over rural ones as far as access to public information related to entrepreneurship is concerned. It would be interesting to examine if our results hold in regions with a wide disparity in urbanization.

\section{Implications}

The implication of our results from a policy point of view is that perceived entrepreneurial ability is important for creating a positive environment for entrepreneurship in a region. In-fact, individuals should not be encouraged to take up entrepreneurial activity unless they develop positive perceptions of their entrepreneurial ability. This is because the task of entrepreneurship is an act of human volition and requires spontaneous drive for problem solving and persistence. A lack of positive attitude about one's ability to solve these problems encountered during the new venture creation process could result in lack of persistence thereby undermining the entrepreneurial initiative. Worse is encouraging segments of the population with high formal education into entrepreneurship if they do not believe that they have the (entrepreneurial) ability to overcome the short-run obstacles of the venturing process. This would lead to under optimization of an individual's human capital and potentially lead to a net loss of human capital in the region. Therefore, policy should be very cautious when promoting entrepreneurship among highly educated individuals.

Secondly, the positive impact of personal knowledge of other entrepreneurs reveals that the motivational impact of entrepreneurial role models is higher when individuals personally know other entrepreneurs. This suggests that promoting entrepreneurship using entrepreneurial role models is more useful when local instead of global entrepreneurs are projected as case studies of successful entrepreneurship.

For potential entrepreneurs, the results of our study imply that specific task specific abilities provide the base necessary for developing perceived entrepreneurial ability. At the same time it is necessary to seek out entrepreneurial role models so that vicarious experience can be obtained. For those with entrepreneurial intentions who undertake formal entrepreneurship training positive perception of entrepreneurial ability could provide the signal necessary to attract potential resources suppliers reading individuals' motivation to pursue and persist with the entrepreneurial career and thus lower entry barriers to new venture creation. 


\section{Conclusion}

Extant studies have indicated that there is a positive relationship between perceived entrepreneurial ability and entrepreneurial activity. In this paper we examined the antecedents of such perceptions. We specifically examined the role of individual-level factors and the entrepreneurial context in influencing perceived entrepreneurial ability in a specific region using a sample of 1961 randomly selected individuals from the working age population of Catalonia region of Spain. Following the cognitive learning theory we used individual level factors like general education, entrepreneurship training and experience (job as well as prior entrepreneurship), age and gender to examine the role that direct and participatory learning play in the influencing perceived entrepreneurial ability. We also hypothesized that an entrepreneurial context comprising personal knowledge about other entrepreneurs and territorial location in a given region would influence perceived entrepreneurial ability. Logistic regression technique was used to analyze the data. The results show that positive perception of entrepreneurial ability in Catalonia results from median level of education, job experience, task specific training in entrepreneurship, prior entrepreneurial experience, age and personal knowledge of other entrepreneurs. The main contribution of our study is that we identify both the micro as well as macro factors that lead individuals to develop entrepreneurial confidence (perceived entrepreneurial ability) in a given region. Considering that positive perceptions of entrepreneurial ability has a significant influence on the decision to initiate nascent entrepreneurial activities our study could help policy makers in designing policy tools that enhances individual's positive perception of their entrepreneurial ability, for instance entrepreneurship related training programs in their regions.

However, it should be noted that positive perceptions of entrepreneurial ability could also be a manifestation of overconfidence. Although over-confidence is important in terms of driving action we caution that such an attribute may not be beneficial in terms of individuals' ability to sustain in a difficult task like entrepreneurship. This study is limited to identifying the antecedents of perceived entrepreneurial ability without examining whether they are symptoms of overconfidence or self-confidence. Secondly this study do not reveal whether positive perception actually lead to the initiation of nascent entrepreneurial activities. Considering that others factors also influence the decision to initiate nascent entrepreneurial activities it would be interesting to examine whether such factors influence the later directly or indirectly through perceived entrepreneurial ability. The main limitation of our study is that our results apply to Catalonia and thus may not be valid for other regions. So, future studies on the determinants of perceived entrepreneurial ability should test our results in other contexts. Moreover, our study do not make any distinction between the nature of education (technical versus non-technical) and didactics. Future study can explore if these two factors influence positive perceptions of entrepreneurial ability.

\section{Endnotes}

${ }^{a}$ There is a difference between perception and sensation. Sensation relates to reception, conversion and transmition of information/data from the outside world using the different sense organs while perception is the interpretation of such raw information/data into a meaniningful whole (Huffman, 2012). 
${ }^{b}$ We use the terms mental representation and mental model to refer to the same construct.

${ }^{\mathrm{c}}$ It should be noted that the mental representation of entrepreneurship could be influenced by affect (feelings and emotions). For instance, those with positive affect would tend to perceive information more favorable than those with neutral or negative affect (Baron, 2008).

${ }^{d}$ Note that competency in the literal sense is sufficiency of abilities in a given domian. So, the difference between ability and competency in the case of the medical student would be whether the student has sufficient knowledge, skills and experience in correctly treating the patient.

${ }^{\mathrm{e}}$ The Hesmer and Lemeshow ( $\left.\mathrm{H} \& \mathrm{~L}\right)$ goodness of fit is shown in Table 3. Note that in the $\mathrm{H} \& \mathrm{~L}$ goodness of fit test a non-significant $\mathrm{p}$ value indicates a better model fit.

Competing interests

The authors declare that they have no competing interest.

Authors' contributions

All authors contributed equally to the paper. All authors read and approved the final manuscript.

\section{Author details}

${ }^{1}$ School of Business, Universidad Del Norte, Km 5 via Puerto Colombia, Barranquilla, Colombia. ${ }^{2}$ Department of Strategy and Innovation, ESC Rennes School of Business, 2 rue Robert d' Arbrissel CS 76522, 35065 Rennes Cedex, France. ${ }^{3}$ Department of Management, Universitat Politècnica de Catalunya (Barcelona Tech), EPSEB, Av. Gregorio Marañón, 4450, 2da planta, 08028 Barcelona, Spain.

Received: 20 August 2014 Accepted: 26 March 2015

Published online: 01 May 2015

\section{References}

Argyris, C. (1991). Teaching Smart People How to Learn. Reflection, 4(2), 1-14.

Arenius, P, \& Minniti, M. (2005). Perceptual variables and nascent Entrepreneurship. Small Business Economics, 24(3), 233-247.

Auken, HV, Fry, FL, \& Stephens, P. (2006). The influence of role models on entrepreneurial intentions. Journal of Development Entrepreneurship, 11(2), 157-167.

Bandura, A. (1977). Self-Efficacy: the exercise of control. New York: Freeman.

Bandura, A. (1989). Social cognitive theory. In R Vasta (Ed.), Annals of child development (Vol. 6, pp. 1-60). Greenwich, CT: JAI Press.

Bandura, A. (2001). Social Cognyive theory: An agentic perspective. Annual Review of Psychlogy, 52, 1-26.

Baron, R. (2008). The role of affect in the entrepreneurial process. Academy of Management Review, 33(2), 328-340.

Bayon, MC, Vaillant, Y, \& Lafuente, E. (2015). Initiating nascent entrepreneurial activities: The relative role of perceived and actual entrepreneurial ability. International Journal of Entrepreneurial Behaviour and Research, 21(1), 27-49.

Becker, GS. (1993). Human Capital: A theoretical and empirical analysis with special reference to Education. Chicago: University of Chicago press.

Bikhchandani, S, Hirshleifer, D, \& Welch, I. (1998). Learning from the Behaviour of Others: Conformity, Fads, and Informational Cascades. The Journal of Economic Perspectives, 12(3), 151-170.

Bosma, NS, Hessels, SJA, Schutjens, VAJM, Van Praag, CM, \& Verheul, I. (2012). Entrepreneurship and role models. Journal of Economic Psychology, 33(2), 410-424.

Cassar, G. (2014). Industry and start-up experience on entrepreneur forecast performance in new firms. Journal of Business Venturing, 29(1), 137-151.

Cauley, KM. (1986). Studying knowledge acquisition: Distinctions among procedural, conceptual and logical Knowledge (Paper presented at the Annual Meeting of the American Educational Research Association 67th). San Francisco, CA.

Conway, MA, Cohen, G, \& Stanhope, N. (1991). On the very long-term retention of knowledge acquired through formal education: Twelve years of cognitive psychology. Journal of Experimental Psychology, 120(4), 385-409.

Clercq, DD, Lim, DSK, \& Oh, CH. (2011). Individual-Level resources and new business activity: The contingent role of institutional context. Entrepreneurship Theory and Practice, 37(2), 303-330.

Cole, M, Sharp, DW, \& Lave, C. (1976). Cognitive consequences of Education: Some empirical evidence and theoretical misgivings. Urban Review, 9(4), 218-233.

Davidsson, P, \& Honig, B. (2003). The role of social and human capital among nascent entrepreneurs. Journal of Business Venturing, 18(3), 301-331.

Dimov, D. (2010). Nascent entrepreneurs and venture emergence, Opportunity confidence, human capital, and early planning. Journal of Management Studies, 47(6), 1123-1153.

Douglas, E (2006). New Venture Risk Taking - Perceptions and Preferences? In Proceedings Babson College Entrepreneurial Research Conference, USA, Indiana. Brisbane, Australia: Queensland University of Technology. http://eprints.qut.edu. au/5532/2/5532.pdf. 
Driga, O, Lafuente, E, \& Vaillant, Y. (2009). Reasons for the Relatively Lower Entrepreneurial Activity levels of Rural Women in Spain. Sociologia Ruralis, 49(1), 70-96.

Duening, TN. (2008). Five minds for the entrepreneurial future: Cognitive skills as the intellectual foundation for next generation entrepreneurship curricula, USASBE 2008 Proceedings - Page 0256.

Dunn, T, \& Holtz-Eakin, D. (2000). Financial capital, human capital, and the transition to self-employment: Evidence from intergenerational links. Journal of Labor Economics, 18(2), 282-305.

Falch, T, \& Massih, SS. (2011). The effect of education on cognitive ability. Economic Inquiry, 49(3), 838-856.

Florida, R. (1995). Towards the learning region. Futures, 27(5), 527-536.

Florida, R. (2005). Cities and the Creative class. New York: Routledge.

Forlani, D, \& Mullins, JW. (2000). Perceived risks and choices in entrepreneurs' new venture decisions. Journal of Business Venturing, 15(4), 305-322.

Fraser, S, \& Greene, FJ. (2006). The effects of experience on entrepreneurial optimism and uncertainty. Economica, 73(290), 169-192.

Gibson, DE. (2004). Role models in career development: New directions for theory and research. Journal of Vocational Behaviour, 65, 134-156.

Gabe, TM, \& Abel, JR. (2011). Specialized knowledge and the geographic concentration of occupations. Journal of Economic Geography, 11(5), 1-19.

Greene, W. (2003). Econometric Analysis. New Jersey: Prentice-Hall.

Grégoire, DA, Corbett, AC, \& McMullen, JS. (2011). The cognitive perspective in entrepreneurship: An agenda for future research. Journal of Management Studies, 48(6), 1443-1477.

Gruber, M, MacMillan, IC, \& Thompson, JD. (2012). From minds to markets: How human capital endowments shape market opportunity identification of technology start-ups. Journal of Management, 38(5), 1421-1449.

Gupta, VK, Turban, DB, Arzu Wasti, S, \& Sikdar, A. (2009). The Role of Gender Stereotypes in Perceptions of Entrepreneurs and Intentions to Become an Entrepreneur. Entrepreneurship theory and practice, 33(2), 397-417.

Hartog, J, Van Praag, M, \& Van Der Sluis, J. (2010). If you are so smart, why aren't you an entrepreneur? Returns to cognitive and social Ability: Entrepreneurs versus Employees. Journal of Management and business strategy, 19(4), 947-989.

Huffman, K. (2012). Psychology in action, 10E. Hoboken, N.J: John Willey and Sons.

Husen, T, \& Juijnman, A. (1991). The contribution of formal schooling to the increase in intellectual capacity. Educational Researcher, 20(1), 17-25.

Johnson-Laird, PN. (1983). Mental models: Towards a cognitive science of language, inference and consciousness. Cambridge, England: Cambridge University Press.

Koellinger, P, Minniti, M, \& Schade, C. (2007). I think I can, I think I can: Overconfidence and Entrepreneurial Behaviour Journal of Economic Psychology, 28(4), 502-527.

Kolb, DA. (1984). Experiential learning: experience as the source of learning and development. Englewood Cliffs, NJ: Prentice Hall. Kelley, DJ, Brush, CG, Greene, PG, \& Litovsky, Y. (2013). GEM 2012 Women's Report, Global Entrepreneurship Research Association.

Kirzner, IM. (1979). Perception, Opportunity and profit: Studies in the theory of entrepreneurship. Chicago: University of Chicago Press.

Klepper, S. (2002). The capabilities of new firms and the evolution of the US automobile industry. Industrial and Corporate Change, 11(4), 645-666.

Krueger, N, \& Carsrud, A. (1993). Entrepreneurial intentions: Applying the theory of planned behaviour. Entrepreneurship and Regional Development, 5(4), 315-330.

Krueger, N, Reilly, M, \& Carsrud, A. (2000). Competing models of entrepreneurial intentions. Journal of Business Venturing, 15(5-6), 411-432.

Krueger, NF. (2005). The cognitive psychology of entrepreneurship. Handbook of Entrepreneurship research, 1(3), 105-140.

Kruger, J, \& Dunning, D. (1999). Unskilled and unaware of it: How difficulties in recognizing one's own incompetence lead to inflated self-assessments. Journal of Personality and Social Psychology, 77(6), 1121-1134.

Lazear, E. (2005). Entrepreneurship. Journal of Labour Economics, 23(4), 649-680.

Lockwood, P, Sadler, P, Fyman, K, \& Tuck, S. (2004). To do or not to do: using positive and negative role models to harness motivation. Social Cognition, 22(4), 422-450.

Lambooy, JG. (2002). Knowledge and urban economic development: An evolutionary perspective. Urban Studies, 39, 1019-1035.

Lechmann, D, \& Schnabel, C. (2014). Are the self-employed really Jacks-of-all- trades? Testing the assumptions and implications of Lazear's theory of Entrepreneurship with German Data. Small Business Economics, 42(1), 59-71.

Liñán, F, Santos, FJ, \& Fernández, J. (2011). The influence of perceptions on potential entrepreneurs. International Entrepreneurship and Management Journal, 7(3), 373-390.

Lafuente, E, Vaillant, Y, \& Serarols, C. (2010). Location decisions of knowledge-based entrepreneurs: Why some Catalan KISAs choose to be rural? Technovation, 30(11-12), 590-600.

Lafuente, E, Vaillant, Y, \& Rialp, J. (2007). Regional Differences in the influence of role models: Comparing the entrepreneurial process of rural Catalonia. Regional Studies, 41(6), 779-795.

McGee, JE, Peterson, M, Mueller, SL, \& Sequeira, JM. (2009). Entrepreneurial Self-Efficacy: Refining the Measure. Entrepreneurship theory and Practice, 33(4), 965-988.

Mitchell, RK, Busenitz, LW, Bird, B, Gaglio, C, McMullen, J, Morse, E, \& Smith, JB. (2007). The Central Question in Entrepreneurial Cognition Research. Entrepreneurship Theory and Practice, 31(1), 1-27.

Mitchell, RK, Randolph-Seng, B, \& Mitchell, JR. (2011). Socially situated cognition: Imagining new opportunities for entrepreneurship research. Academy of Management Review, 36(4), 774-778.

Nanda, R, \& Sorensen, JB. (2010). Workplace peers and entrepreneurship. Management Science, 56(7), 1116-1126.

Nauta, M, \& Kokaly, M. (2001). Assessing role model influences on students' academic and vocational decisions. Journal of Career Assessment, 9(1), 81-99.

Neisser, U. (1967). Cognitive psychology. New York: Appleton-Century-Crafts.

Palich, LE, \& Bagby, DR. (1995). Using Cognitive Theory to explain Entrepreneurial Risk-taking: Challenging the conventional wisdom. Journal of Business Venturing, 10(6), 425-438. 
Peterman, NE, \& Kennedy, J. (2003). Enterprise Education: Influencing Students' Perceptions of Entrepreneurship. Entrepreneurship theory and practice, 28(2), 129-144.

Pomerantz, J. (2003). Perception. Encyclopedia of Cognitive Science, 3, 527-537.

Reynolds, P, Bosma, N, Autio, R, Hunt, S, Bono, ND, Servais, I, Lopez-Garcia, P, \& Chin, N. (2005). Global Entrepreneurship Monitor(GEM): Data collection, design and implementation. Small Business Economics, 24(3), 205-231.

Sarasvathy, SD, Dew, N, Velamuri, SR, \& Venkataraman, S. (2005). Three views on entrepreneurial opportunities. Handbook of Entrepreneurship Research, 1(3), 141-160.

Shane, S. (2000). Prior knowledge and the discovery of Entrepreneurial opportunities. Organization Science, 11(4), 448-469.

Shane, S, \& Venkataraman, S. (2000). The promise of entrepreneurship as a field of research. Academy of management review, 25(1), 217-226

Shapero, A, \& Sokol, L. (1982). Social dimensions of entrepreneurship. In CA Kent, DL Sexton, \& KH Vesper (Eds.), Encyclopaedia of entrepreneurship (Vol. 72-90). Englewood Cliffs, NJ: Prentice-Hall.

Simon, M, Houghton, S, \& Aquino, K. (2000). Cognitive bias, risk perception and venture formation: How individuals decide to start companies. Journal of Business Venturing, 15(2), 113-134.

Sternberg, RJ. (2004). Successful intelligence as a basis for entrepreneurship. Journal of Business Venturing, 19, 189-201.

Thébaud, S. (2010). Gender and Entrepreneurship as a career choice do self-assessments of ability matter. Social Psychology Quarterly, 73(2), 288-304.

Townsend, DM, Busenitz, LW, \& Arthurs, JD. (2010). To start or not to start: Outcome and ability expectations in the decision to start a new venture. Journal of Business Venturing, 25(2), 192-202.

Unger, JM, Rauch, A, Frese, M, \& Rosenbusch, N. (2011). Human Capital and Entrepreneurial success: A Meta-analytic review. Journal of Business Venturing, 26(3), 341-358.

Ucbasaran, D, Westhead, P, \& Wright, M. (2008). Opportunity Identification and Pursuit: Does Entrepreneur Human capital matter? Small Business Economics, 30(2), 153-173.

Vaillant, Y, \& Lafuente, E. (2007). Do Different Institutional Framework condition the influence of local fear of failure and entrepreneurial examples over entrepreneurial activity? Entrepreneurship and Regional Development, 19(4), 313-337.

Verheul, I, Thurik, R, Grilo, I, \& Van der Zwan, P. (2012). Explaining preferences and actual involvement in selfemployment. Gender and the entrepreneurial personality Journal of Economic Psychology, 33(2), 325-341.

Von Graevenitz, G, Harhoff, D, \& Weber, R. (2010). The Effects of Entrepreneurship Education. Journal of Economic Behaviour and Organization, 76(1), 90-112.

Wood, RE, \& Bandera, A. (1989). Impact of conceptions of ability on self-regulatory mechanisms and complex decision making. Journal of Personality and Social Psychology, 56, 407-415.

\section{Submit your manuscript to a SpringerOpen ${ }^{\circ}$} journal and benefit from:

- Convenient online submission

- Rigorous peer review

- Immediate publication on acceptance

- Open access: articles freely available online

- High visibility within the field

Retaining the copyright to your article 